\title{
Advancing Teacher Skills while Developing New Learning Materials for Professional Health Education*
}

\author{
Andreia Araujo Lima Torres, Gardênia da Silva Abbad, Kelb Bousquet-Santos \\ University of Brasília, Brasília, Brazil \\ Email: andreiat@gmail.com, gardenia.abbad@gmail.com, kelb@unb.br
}

Received 21 May 2014; revised 25 June 2014; accepted 5 July 2014

Copyright (C) 2014 by authors and Scientific Research Publishing Inc.

This work is licensed under the Creative Commons Attribution International License (CC BY). http://creativecommons.org/licenses/by/4.0/

(c) (i) Open Access

\section{Abstract}

This paper describes the experience of a PhD candidate during during her teaching training period within the Human nutrition course in a Brazilian public university. The experience provided the doctoral candidate the opportunity to study and deepen knowledge in the field of educational psychology, including learning theories, instructional theories and instructional design. As a result, the Human Nutrition Course was restructured and new learning material supported by Information and Communication Technologies was produced and used during the semester. As a result, it was reported by students a greater level of satisfaction and learning. The supervised practice in teaching was perceived as an important and useful moment by the doctoral candidate as it enabled interactions between research and teaching, the improvement of classes, media and learning strategies. It also enabled a greater comprehension of the professors' role and its importance in the educational process. Finally, the paper discusses new ICT skills recommended in teaching in undergraduate health courses.

\section{Keywords}

Teacher Development, Teaching Skills, Nutrition, Health Education

\section{Introduction}

Acoording to Perrenoud (2000) teachers must develop ten families of skills: 1) definition and organization of learning situations; 2) assessment of learning; 3) designing differentiating learning devices; 4) involving students in their own learning; 5) teamwork; 6) participation in the administration of the educational institution; 7)

${ }^{*}$ The present research was supported by CAPES and DPP/UnB.

How to cite this paper: Torres, A. A. L., da Silva Abbad, G., \& Bousquet-Santos, K. (2014). Advancing Teacher Skills while Developing New Learning Materials for Professional Health Education. Creative Education, 5, 1254-1259. 
communication and involvement with those responsible for students; 8) using Information and Communication Technologies (ICT); 9) facing duties and dilemmas of the profession; 10) administration of their own continuing education.

Teaching is a part of the duties of researchers and teachers of universities. For the student to learn, a number of strategies can be used. According to Hattie (2003), with regard to teaching, the most efficient strategies include immediate and individualized feedback, quality classes, implementation of remediative strategies, promotion of a friendly environment in class, setting clear objectives, providing exercises, using advanced organizers, assessing through tests, as well as using simulations, games, computer instruction and different media supported by ICT.

For UNESCO $(2002,2008)$, modern teachers need to develop a set of skills to develop their work in the information and communication society. Among them is the ability to use the ICTs such as: 1) identifying and understanding the functions of the major components of hardware and software for daily use; 2) using productivity tools—-word processors, spreadsheets and databases-with skill and creativity; 3) composing and sharing documents, presentations and graphical representations; 4) communicating and sharing through the Internet; 5) forming communities of knowledge; 6) supporting and using these technologies to develop students' skills; 7) seeking and analyzing information; 8) solving problems and making decisions; 9) educating responsible and ethical citizens; 10) understanding the moral, social and economic issues involved in the use of ICTs in education.

However, health professionals are not trained to develop these skills. Thus, the teaching training period is an opportunity for their development for all that want to pursue a career as a university professor, contributing to increase the levels of quality of teaching and research (Chamliam, 2003). Also, according to a review disclosed by the Australian Council for Education Research, students and their willingness to study are responsible for $50 \%$ of learning, whilst $30 \%$ are a result of the strategies adopted by the teacher (Hattie, 2003). Therefore, teacher training and development is a key for the qualification of new health professional.

In this study, a dietitian and doctorate candidate, had the opportunity to perform her teacher training during the first semester of 2013, within the Basic Human Nutrition Course, offered at a public university in Brazil. The purpose of this paper is to describe the skills developed during the period.

\section{Method}

The teacher training is a mandatory activity in master and doctorate programs in Brazil. The current paper presents the report of an experience held during the first semester of 2013, under the supervision of the teacher responsible for the Basic Human Nutrition course, and a psychologist who was also an instructional designer. The course, offered to health students, provided 2 credits corresponding to 30 presence hours.

With the specific aim of increasing the satisfaction and knowledge of the students on the topic of nutrition, principles of cognitive and instructional theories were used to redesign the course. For that purpose the following activities were performed: 1) assessment of student's characteristics (age, gender, course and semester enrolled); 2) application of a questionnaire to assess student's skills on information and communication technologies; 3) interview with the teacher responsible for the course; 4) syllabus review; 5) definition and classification of educational goals; 6) sequencing of content and classes; 7) definition of instructional procedures; 8) planning the content for each unit; 9) development of new support materials—audio and video; 10) development of study guides for each module; 11) development of assessment tools; 12) development and validation of instruments to assess satisfaction of participants to the course and performance of professors; 13) training tutors; 14) teaching; 15) writing and validation of test items; 16) correction and release of test notes; 17) virtual tutoring.

The assessment of student's characteristics was made through a survey applied in person. To complement the profile assessment, a previously validated questionnaire (Torres, Abbad, \& Bousquet-Santos, 2013) on students' ability to use information and communication technologies was applied as well during the same day, in March 2013.

The course syllabus, the professor's interview and the Food Guide for the Brazilian population were used as the basis for objectives definitions and content development. The guide emphasizes the conceptual basis that any health professional needs about nutrition (Brasil, 2012). To set the educational goals objectives were described in terms of observed knowledge, skills and attitudes. Bloom's revised taxonomy (Anderson et al., 2001) was used to classify learning goals. Educational procedures and learning situations designed to facilitate the acquisition of the skills previously described were defined. There are different strategies, techniques or instructional events used for the learner to acquire the competencies defined in the instructional objectives (Borges-Andrade, 
1982). The proposed course included fifteen face-to-face weekly meetings lasting $1 \mathrm{~h}$ and 40 minutes each. A virtual learning environment (Moodle) was used for the provision of materials to students (Figure 1).

Through the hyperlinks the student could access the study guide for each class as well as the materials provided in the course such as texts, audio or videos files, class slides and instructions for the tasks to be performed. During the period of the research 8 audio podcasts and 6 video classes were produced and delivered to students. The software Garage Band was chosen for the recording and edition of the audio programs. Each audio podcasts lasted an average of 5 minutes. The recording consumed about 20 minutes and the editing took around $40 \mathrm{mi}-$ nutes each. The themes of the audio podcasts included "Food Guides", "Total Energy Expenditure and Total Energy Value of Foods", “Nutritional Status of the Brazilian Population”, "Nutritional Assessment”, "Breastfeeding", "Nutrition during Pregnancy", "Nutrition for Seniors" and "Hydration and Physical Activity".

For the recording and editing of the video classes, the software KeyNote, Screen Flow and iMovie were used. The production of the slides, the recording and editing of each video class consumed an average of 6 hours. The themes were "The relationship between nutrition and the environment", "Fundamentals of Nutrition", "The food guide pyramid", "Relationship between lifestyle and aging", "Enteral Nutrition” and "Parenteral Nutrition”. All material was made available to students 1 week before classes. Were also made available in the virtual learning environment news forums, discussion forums, course syllabus, bibliography and evaluation criteria.

For the development of instruments to assess satisfaction of participants regarding the course, the professors, the materials, the virtual environment and activities the scales validated by Zerbini (2007), and by Abbad, Zerbini and Borges Ferreira (2012) were adapted. The final instrument consisted of 71 questions about scheduling, teaching resources, applicability and usefulness of the course, learning efficacy, performance of teachers, assessment procedures and reactions regarding Moodle environment. The questions were associated to a Likert type 11-point scale, ranging from 0 (bad) to 10 (excellent). To measure participants' satisfaction, the score of the scale items were summed and the arithmetic mean was calculated. In order to facilitate data analysis, the percentage of satisfaction of participants for each scale was also calculated.

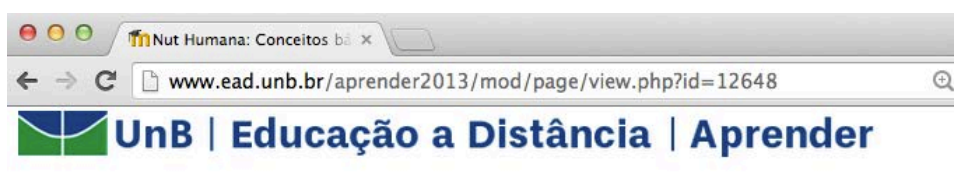

Minha página inicial $\gg$ Meus cursos $\triangleright$ Campus de Ceilândia $\triangleright$ Nut Humana $\triangleright$ Materiais da disciplina

\section{Conceitos básicos}
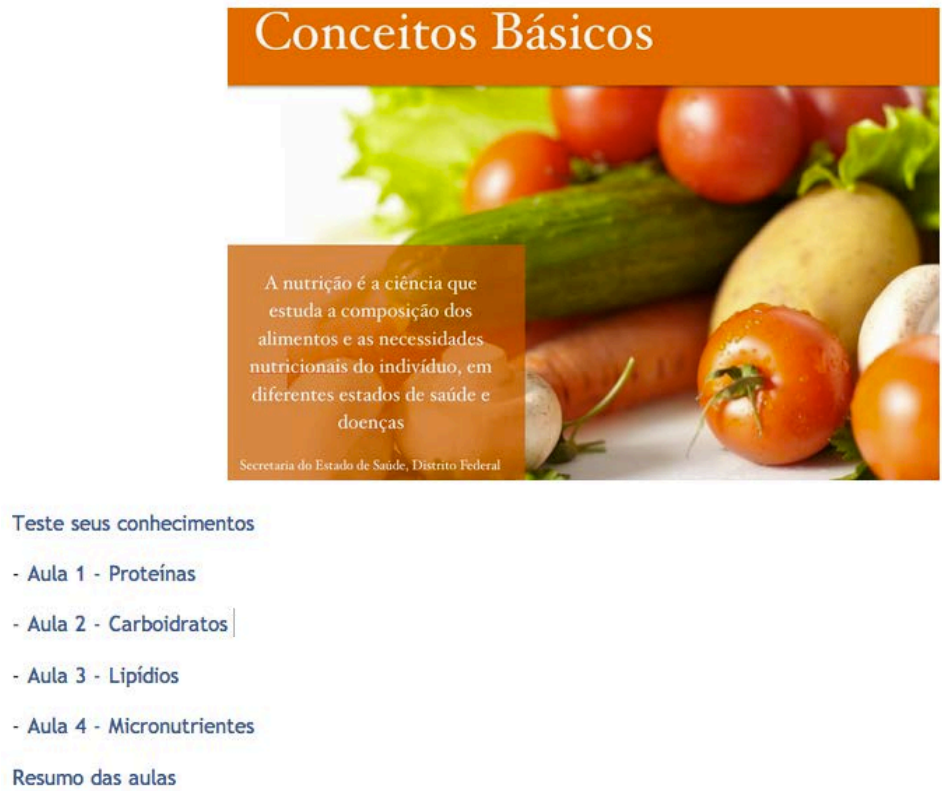

Figure 1. Classes at Moodle. 


\section{Results}

In the planning phase, a survey was applied in person with students in order to assess their characteristics. All students $(n=47)$ completed the questionnaire in class. Most students were female $(n=40,85.1 \%)$, were in the fifth semester $(n=30,53.8 \%)$, were nursing students $(n=32,68.1 \%)$, and 20 years old or less $(n=37,80.9 \%)$.

To complement the profile assessment, a previously validated questionnaire (Torres, Abbad, \& BousquetSantos, 2013) on students' ability to use information and communication technologies was applied as well. It was also applied at the beginning of the term, in person and all students answered it. The results showed that most participants had very low difficulties in using ICTs and those were not relevant and did not prevent the adoption of new media in support classroom activities. All students reported having already attended some course in which video, audio, social media and the e-learning platform Moodle were used, thus it was not necessary to train students to use these technologies.

The analysis of the food guide for the Brazilian population and the syllabus of the course allowed the description of the skills required for health professionals who act in Sistema Único de Saúde (SUS), the public health system in Brazil. From this study the objectives were rewritten in terms of observable behaviors and new materials (slides, texts, podcasts and video classes) were prepared in order to meet the needs of students. All content was made available to students through Moodle, one week prior to class attendance. In order to record and edit audio podcasts and video classes the doctoral candidate had to develop new competences, learn how to use the software previously described and study instructional design theories in order to provide materials that could support student's learning.

At the end of the semester the satisfaction questionnaire was administered by Moodle. The same was answered by 39 students, corresponding to $82.97 \%$ of them. Overall, the course was well evaluated by students (mean = 8.3); however, some items can be highlighted as deficient (items with a mean less than 7.0). According to students' opinion the practical situations were insufficient and the amount of activities was considered excessive. In addition, the group did not consider forums and portfolios relevant for learning. Regarding the degree of student satisfaction with teachers, the results show that the assessment of students was quite high, and the faculty had an average of 9.11 (doctoral candidate) and 9.5 (course professor).

Students also made considerations about the materials and strategies used in the discipline. In general, they preferred the video classes to audio podcasts. Half (50\%) considered audio podcasts very important for learning, whereas $29 \%$ considered them fairly important. No student considered them unimportant and $71 \%$ reported that they would like them to be kept or used in other disciplines. Only 7\% of students would like the audio podcasts to be eliminated. As for the video classes 43\% rated them as very important for the learning, while 36\% thought they were fairly important. In this group, $86 \%$ would like that the video classes were maintained in the course or adopted by other professors during the year.

Two students failed the course. In the future, new tests will be made to verify the correlation between satisfaction of students with the course and their grades. As there was no time available to apply pre-tests within the semester, the analysis of learning gain was not possible.

\section{Discussion}

The teacher training period provided the doctoral candidate the opportunity to participate actively in the planning, development and evaluation of the students enrolled in a basic nutrition course. During the planning period it was necessary to research different types of learning materials in order to provide students with different media and opportunities to learn. Traditional materials such as texts and slides were maintained and new media was added. Meta-analysis conducted in 2013 by Cook et al. (2013) showed that the variation of teaching strategies is important for both satisfaction and learning outcomes of students.

One way to decide for the challenges to be adopted is to take into account the learning needs of the student. Moreover, the selection of instructional materials must meet the educational objectives of the course or discipline and question, so that the strategies proposed are adequate to provide a better educational experience, both in terms of satisfaction and learning.

Audio podcasts have been shown to be useful and easy to implement, as they require little time to be recorded, edited and implemented. In this study the majority of the students appreciated them. To Cebeci and Tekdal (2006) the flexibility provided by podcasts is due to their possibility to be heard anywhere and anytime. Moreover, the fact that these media make possible learning through listening makes them more attractive to students 
with a preference for such learning strategy.

The preference for video classes was even greater. One of the possible reasons why students have great satisfaction with video lessons is the ability of this media to unite audio and image, decreasing the cognitive load (Mayer \& Moreno, 2003). Moreover, videos allow student to control the pace of learning, as they can stop, pause, repeat and review the material several times (Schreiber, Fukuta, \& Gordon, 2010).

\section{Final Considerations}

The teacher training period proved to be very beneficial, aiding the doctoral candidate to develop new teaching and research skills, as well to reflect about professor's roles. It was observed that the adequate planning of educational activities improves student's satisfaction with the role process. The production of materials, especially video classes, is very complex and time consuming. Thus it is suggested the deployment of a university repository so that professors can share and use new media in education more easily.

A weakness of the study was the absence of a pretest. As item construction for formal evaluations is a complex and time consuming process, there was no available time to initiate the term with a validated instrument. Thus, further studies are still needed enabling a better understanding of the effectiveness of the strategies adopted during the teacher training period.

The process also showed that the educational process requires constant adjustments and restatements. The results of this short period showed the need of further improvements in the course. Also an external evaluation of the materials built would be ideal.

Even with the weaknesses showed the teaching period was considered extremely rich and useful as it enabled the interaction between research and teaching, as well as the improvement of the $\mathrm{PhD}$ candidate' skills related to the use of varied learning strategies and the development of new learning materials. It also deepened the knowledge of postgraduate student on the teacher's role and its importance in the educational process, from the needs analysis to the course evaluation. As in Brazil, a multidisciplinary team is not often available for reshaping courses. The professor must take on other roles such as instructional designer and producer of multimedia content. Besides the didactic competence the professor needs technological competencies to be able to produce effective new learning materials based on ICT. The software used in the present study was chosen because of their simplicity and facility to be dealt and learned. But as the ICT competence varies a lot among people, teacher education programs designed to prepare teachers to integrate technology in their lessons are still required in Brazil.

\section{References}

Abbad, G. S., Zerbini, T., \& Borges-Ferreira, M. F. (2012). Medidas de reação a cursospresenciais. In G. S. Abbad et al. (Ed.), Medidas de avaliaçãoemtreinamento, desenvolvimento e educação: Ferramentasparagestão de pessoas. Porto Alegre: Artmed.

Abbad, G. S., Zerbini, T., Carvalho, R. S., \& Meneses, P. P. M. (2006). Planejamento Instrucionalem TD \& E. In J. E. BorgesAndrade, G. S. Abbad, \& L. Mourão (Eds.), Treinamento, Desenvolvimento e Educaçãoem Organizações e Trabalho: fundamentospara a gestão de pessoas (pp. 289-231). Porto Alegre: Artmed.

Borges-Andrade, J. E. (1982). Avaliaçãosomativa de sistemasinstrucionais: Integração de trêspropostas. Tecnologia Educacional, 11, 29-39.

Brasil (2012). Ministério da Saúde. Coordenação Geral da Política de Alimentação e Nutrição. Guiaalimentarpara a populaçãobrasileira: Promovendoaalimentaçãosaudável. Brasília: Ministério da Saúde. http://dtr2001.saude.gov.br/editora/produtos/livros/pdf/05_1109_M.pdf

Cebeci, Z., \& Tekdal, M. (2006). Using Podcasts as Audio Learning Objetcts. Interdisciplinary Journal of Knowledge and Learning Objects, 2, 47-57.

Chamliam, H. C. (2003). Docêncianauniversidade: professoresinovadoresna USP. Cadernos de Pesquisa, 1, 41-64.

Cook, D. A., Hamstra, S. J, Brydges, R., Zendejas, B., Szostek, J. H., Wang, A. T., Erwin, P. J., \& Hatala, R. (2013). Comparative Effectiveness of Instructional Design Features in Simulation-Based Education: Systematic Review and Meta Analysis. Medical Teacher, 35, e867-e898. http://dx.doi.org/10.3109/0142159X.2012.714886

Hattie, J. (2003). Teachers Make a Difference. What Is the Research Evidence? (pp. 1-17) Australian Council for Educational Research Annual Conference on Building Teacher Quality. Auckland: University of Auckland. https://cdn.auckland.ac.nz/assets/education/hattie/docs/teachers-make-a-difference-ACER-(2003).pdf

Perrenoud, P. (2000). Deznovascompetênciasparaensinar (162 p). Porto Alegre: Artmed. 
Torres, A. A. L., Abbad, G. S., \& Bousquet-Santos, K. (2013). Validation of a Questionnaire on ICTs (Information and Communication Technologies) Skills of Undergraduate Health Students in Brazil. Psychology Research, 3, 512-517.

UNESCO. Division of Higher Education (2002). Information and Communication Technologies in Education: A Curriculum for Schools and Programme of Teacher Development (150 p).

UNESCO (2014). Estándares de competência en TIC paradocentes (28 p). http://www.oei.es/tic/UNESCOEstandaresDocentes.pdf

Zerbini, T. (2007). Avaliação da Transferência de treinamentoemcurso a distância. Doctorate Thesis, Brasília: University of Brasília. 
Scientific Research Publishing (SCIRP) is one of the largest Open Access journal publishers. It is currently publishing more than 200 open access, online, peer-reviewed journals covering a wide range of academic disciplines. SCIRP serves the worldwide academic communities and contributes to the progress and application of science with its publication.

Other selected journals from SCIRP are listed as below. Submit your manuscript to us via either submit@scirp.org or Online Submission Portal.
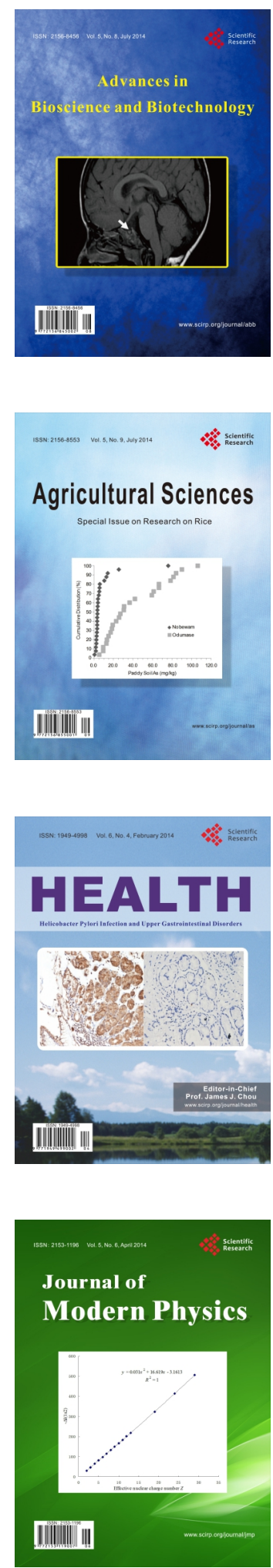
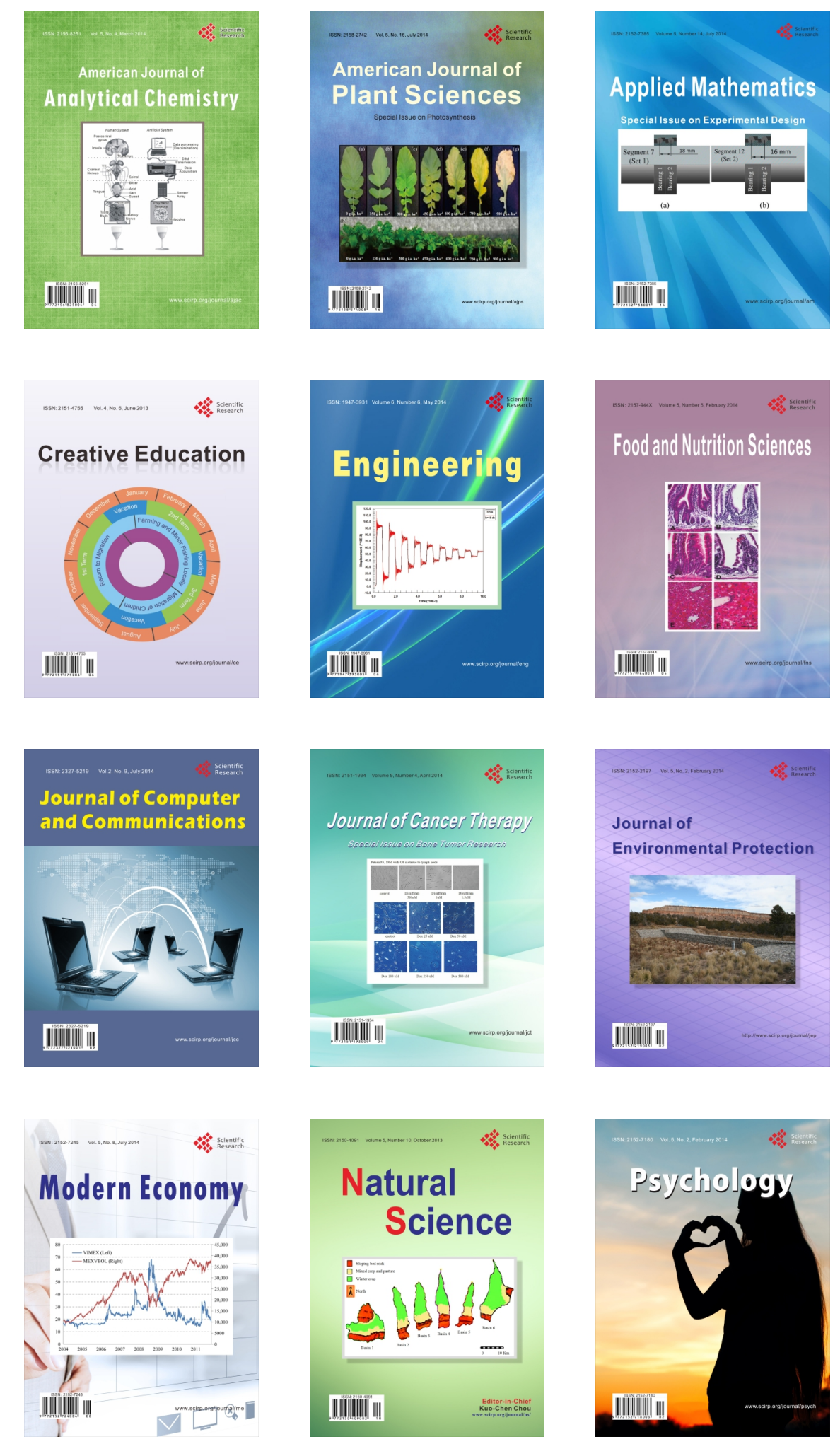